\title{
IAMJ
}

INTERNATIONAL

AYURVEDIC

MEDICAL JOURNAL

ISSN: 2320-5091

Impact Factor: 6.719

\section{URDHVA SHAKHAGATA SNAYU MARMA AND ITS CLINICAL IMPORTANCE: A REVIEW ARTICLE}

\author{
Ishan Malhotra ${ }^{1}$, Sakshi $^{2}$, Subhash Upadhyay ${ }^{3}$, Jannu Manohar $^{4}$ \\ ${ }^{1}$ PG Scholar Deptt of Rachana Sharir \\ ${ }^{2}$ Assistant Professor Deptt of Rachana Sharir \\ ${ }^{3}$ Professor \& H.O.D. Deptt of Rachana Sharir \\ ${ }^{4}$ Professor Deptt of Rachana Sharir \\ Sriganganagar College of Ayurvedic Science \& Hospital, Tantia University, \\ Sriganganagar - 335001, India
}

Corresponding Author: docmalhotra88@gmail.com

https://doi.org/10.46607/iamj3509092021

(Published Online: September 2021)

Open Access

(C) International Ayurvedic Medical Journal, India 2021

Article Received: 23/08//2021 - Peer Reviewed: 03/09/2021 - Accepted for Publication: 04/09/2021

\section{Check for updates}

\section{ABSTRACT}

In Ayurveda classics, Marma is illustrated as the vital point in the human body and its knowledge plays an important role in Sharir Rachana. Marma was first documented by Acharya Charak but the detailed description of Marma Sharir is available in Sushruta Samhita. Acharya Sushruta stated every aspect of Marma like definition, types, signs, and symptoms related to injury of Marma. Marma is a very important structure present in the body which causes pain or even death when getting injured. According to Acharya Sushruta in the description of Ekadash Indriya Hasta and Paad are included under the five Karmendriya and their function is mentioned as Aadan and Vihar respectively and Hasta (hand) is considered as the most important/superior Yantra among all the Yantras by Acharya Susruta. Although each part of the human body is important still extremities possess the most importance as all body activities depend on limbs as without limbs existence of the human body is hard to imagine. So Anatomical interpretation of Urdhva Shakhagata Snayu Marma along with its clinical importance is very much needed in the present era. An attempt has been made to explore structures present in Urdhva Shakhagata Snayu Marma through cadaveric dissection. 
Keywords: Ekadash Indriya, Snayu Marma, Yantra.

\section{INTRODUCTION}

The site where there is a conglomeration of Mamsa, Sira, Snayu, Asthi, Sandhi, is considered as Marma. These are especially the site of Prana. The total numbers of Marma have described in Samhitas are 107 , each of them falls under five different headings based on region, structure, number, measurement, and prognosis. In Sanskrit, the word Snayu means to Bind. According to Ayurvedic classics, Snayu has been explained as that which resembles a fibrous structure. It is said to be a structure that binds the joints and enables the body to bear weight. Sinew is the term used for tendon in older texts. It means a fibrous tissue that supports and gives strength. This term has a similar meaning to that of Snayu. Sinew term is also used for nerve and the term nerve means to give strength or vigour. It means a band, bandage, ribbon, or bundle. There are many structures like tendons, ligaments, nerves, muscle tissue etc. which can be related to Snayu. In this context, Acharya Sushruta has mentioned that on the injury of Snayu, bones, muscles, blood vessels and joints do not inflict the person so as ligament. And one who knows ligament can extract the hidden foreign body from the person's body. According to Acharya Sushruta in the description of Ekadash Indriya Hasta and Paad are included under the five Karmendriya and their function are mentioned as Aadan and $\operatorname{Vihar}^{[4]}$ respectively and Hasta (hand) is considered as the most important/superior Yantra among all the Yantras by Acharya Sushruta. Although each part of the human body is important still extremities possess the most importance as all body activities depend on limbs as without limbs existence of the human body is hard to imagine.

As Present life is very fast and furious and causes so many injuries during accidents, sport and maybe during daily activities which lead to severe pain, deformity or even death. As Marma are vital points of the body they should be protected from injuries

\section{AYURVEDIC REVIEW}

Among the classification of Marma, Snayu Marma is classified as 27 in number by Acharya Sushruta. Among 27 Snayu Marma five are in Urdhva Shakha, these are - Kshipra, Kurcha, Kurchshira, Ani and Kakshadhara.

\section{Kshipra Marma}

According to Shabdkosh, the meaning of Kshipra.

- The part of the hand between the thumb and the forefinger.

- Quickly, speedily, immediately, with a short

Anatomical exploration (structure involved in the region of Kshipra Marma)

- Adductor pollicis muscle of thumb (thenar muscle).

- First lumbrical muscle.

- First palmar and dorsal interosseous muscle.

- Princeps pollicis artery.

- Radialis indicis artery

- Palmar branch of the median nerve

- Dorsal venous network of hand

- Dorsal digital artery and Dorsal metacarpal artery of radial artery

- The dorsal digital nerve of the radial nerve.

Anatomical exploration (structure involved in the region of Kurcha Marma)

- Tendon of Extensor digitorum.

- Tendon of flexor carpi radialis.

- Tendon of flexor pollicis longus.

- Tendon of flexor digitorum superficialis (sublimus) and profundus.

- Tendon of extensor indicis with its synovial sheath.

- Tendon of extensor pollicis longus, brevis and extensor carpi radialis longus, brevis with its synovial sheaths.

- Tendon of abductor pollicis longus.

- Radial artery and its dorsal carpal branches.

- Carpo metacarpal ligament.

- Inter carpal ligament. 
- The synovial sheath of the flexor tendon.

- Median and Radial nerve.

- Thenar muscles.

Anatomical exploration (structures involved in the region of Kurchshira Marma).

- Tendon of Extensor digitorum.

- Tendon of flexor carpi radialis.

- Tendon of flexor pollicis longus.

- Tendon of flexor digitorum superficialis (sublimus) and profundus.

- Tendon of extensor indicis with its synovial sheath.

- Tendon of extensor pollicisl ongus, brevis and extensor carpi radialis longus, brevis with its synovial sheaths.

- Tendon of abductor pollicis longus.

- Extensor retinaculum.

- The flexor retinaculum (transverse carpal ligament or anterior annular ligament).

- Radial artery.

- Radial and median nerve.

Ani Marma

According to Shabdkosh, the meaning of Ani.

- A boundary limits

- The part of the leg just above the knee corresponding part in the upper limb is just above the elbow.

\section{Ani Marma has the following features}

- Number-2.

- Site-3 Angul above the elbow.

- Pramana-Ardhanguli Pramana.

- Marma type-Snayu Marma.

- Prognostically- Vaikalyakara Kara Marma.

Anatomical exploration (structures involved in the region of Ani Marma)

- Tendon of biceps brachii muscle and Triceps brachii muscle

- Brachial artery and its branches. Profunda brachii artery.

- Radial collateral artery. Inferior ulnar collateral artery.

- Cephalic and basilic veins.
- The median nerve, Radial nerve, Musculocutaneous nerve, and ulnar nerve

\section{Vidha Lakshan}

The incidence of trauma takes place in road accidents and sports injuries. Pedestrians also get injured. There are so many references from Vedas regarding the attack on Marma Sthana of enemies and protecting one's Marma by wearing protectants. Even in today's fast life, it is very important to protect our Marma Sthanas because of heavy road traffic which results in accidents causing injury to Marmas. Developing Science invents new Military armaments increasing the severity of injury during the war.

If Kshipra Marma is injured, it causes convulsions and death. Kshipra is Kalantra pranhara Marma. They are constituted predominantly by Soma (Jala) and Agni. Agni affects faster, whereas Soma (Jala) affects slowly, as a result, the affected person may die within a month.

Other associated symptoms are Dhatu kshaya and Kshayaj Vedana (emaciation and pain due to emaciation.).

If Kurcha Marma is injured, it causes reeling and trembling of hand. Below the wrist joint on both sides Kurchashira Marma is present; its injury causes pain and inflammation. If Ani Marma is injured, it causes severe swelling and stiffness in the hand. If Kakshadhara marma is injured, it causes paralysis. Ani, Kurcha and Kakshadhara are Vaikalyakara Marma. Vaikalyakara Marma is considered by Soma Guna; by the effect of stability and Sheeta Guna (cold qualities), the Soma (Jala) Dhatu supports the Pranas. Thus, injury causes deformity but rarely on severe injury may cause death. Proper treatment by an efficient Vaidya may limit the risk of deformity only.

\section{According to Astang Hridya}

When Snayu Marma is injured, there will be bending of the body, convulsion, very severe pain, inability for riding, sitting etc, distortions or even death.

\section{Clinical importance of Marma}

The knowledge of the Marmas constitutes half of the Shalya, as it is known that the person injured at the 
site of Marma does not survive Even if the person stays alive by good efforts made by an efficient Surgeon, suffer from any kind of deformity.

Measurements of Marmas is quite important to a surgeon, as they should not be injured, further it is also helpful to omit the areas of neighbouring Marmas that may also produce severe hazards. Marmas contain Soma (Kapha), Marut (vata), Teja (Pitta), Sattva, rajas, tamas and Bhutatma (atma along with Bhuttas). Hence, a Person, on injury to the Marma may not alive.

Any injury to the Marma causes death or deformity. Any pathological abnormalities that develop at the sites of Marma will consequence to grave conditions, careful and precautions treatment of good physician may not help to cure the disorder. Snayu is considered as one of the sites for the development of wounds where healing is very difficult and delayed. Detailed knowledge of Snayu Marma is important from the surgical point of view, Surgical procedures like Agnikarma, Ksharkarma and Shastrakarma are used as part of the surgery, with proper knowledge of Marma Sthana we may perform the procedures without any complication

\section{DISCUSSION}

The prognosis of injury depends upon the site of injury, depth of injury, force at which the injury is caused. However, the site and structures involved are the factors that discriminate the severity of the wounds. The Kshipra Marma can be sometimes turned into Sadyopranahara is mentioned by Acharya Sushruta. Akshepaka is one of the common symptoms of Vaat Vikara mentioned by Acharya Sushruta and Vaghbhata. In Akshepaka the Vayu entering Dhamani causes severe spasms and convulsions in the individual. In this context, Dalhana has interpreted Dhamani as Nadi which possibly indicates the involvement of the nervous system in Vaat Vyadhi. It has been mentioned that if any injury oc- curs to the Kshipra Marma, then this will lead to severe blood loss which will further result in Vata prakopa.

Any injury to all structures which are related to Kakshadhara Marma such as compression of the trunk of the brachial plexus in aneurysm of axillary artery, injury to the upper trunk of the brachial plexus i.e., Erb's paralysis, injury to the lower trunk of the brachial plexus i.e., Klumpke's paralysis, axillary nerve injury due to shoulder dislocation, musculocutaneous nerve injury may lead to following impairments such as inability to flexion of elbow and depression of the shoulder joint, Nerve injury may lead to paralysis and wasting of the muscles of the arm.

\section{CONCLUSION}

Kshipra Marma can be compared with the thenar space and its contents. Injury to these structures may lead to bleeding. If it is infected with tetanus, then death occurs due to convulsion. That is why it is counted under Kalantrapranhara Marma. Kurcha Marma can be compared with flexors and extensor tendon of hand and intercarpal ligament. Injury to these structures may lead to reeling and trembling. That's why it is counted under Vaikalyakara Marma. Kurchashira Marma can be compared with radial collateral ligament and transverse carpal ligament. Injury to these ligaments may lead to intense pain and swelling. That's why it is counted under Rujakara Marma.

\section{REFERENCES}

1. Ghanekar Bhaskar Govind. Sushruta samhita: sarirasthanam Ayurvedarahsyadipika hindi commentary. New Delhi: Meharchand Lachhmandas publication. Reprint, Nov 2008; 6(22): 186.

\section{Source of Support: Nil Conflict of Interest: None Declared}

How to cite this URL: Ishan Malhotra et al: Vrdhva Shakhagata Snayu Marma And Its Clinical Importance: $\mathcal{A}$ Review Article. International Ayurvedic Medical Journal \{online\} 2021 \{cited September 2021\} Available from: http://www.iamj.in/posts/images/upload/2151_2154.pdf 